\title{
PEMBERDAYAAN MASYARAKAT TANA TORAJA MELALUI KEGIATAN WIRAUSAHA SUKADE BUAH KUNRU GUNA MENUMBUHKAN MINAT BERWIRAUSAHA
}

\author{
Harmita Sari ${ }^{11}$, Altri Wahida1), Samsinar'1) \\ 1)Universitas Muhammadiyah Palopo. Jalan Jendral Sudriman No. Km. 03, Binturu, Wara Selatan, Kota Palopo, Sulawesi \\ Selatan 91922, Indonesia
}

Corresponding Author: Harmita Sari/Altri Wahida

Email: harmitasari93@gmail.com, Telp: +6285240889393

\section{Diterima 26 April 2021, Direvisi 26 Juni 2021, Disetujui 30 Juni 2021}

\begin{abstract}
ABSTRAK
Tujuan dari kegiatan ini adalah meningkatkan minat berwirausaha masyarakat tana toraja melalui pemberdayaan dengan kegiatan wirausaha. Wirausaha adalah proses mengidentifikasi, mengembangkan, dan membawa visi ke dalam kehidupan. Visi tersebut bisa berupa ide inovatif, peluang, cara yang lebih baik dalam menjalankan sesuatu. Hasil akhir dari proses tersebut adalah penciptaan usaha baru yang dibentuk pada kondisi risiko atau ketidakpastian. Metode yang digunakan dalam kegiatan ini adalah dengan pelatihan membuat keterampilan dalam membuat produk dari bahan buah kunru, yaitu sukade yang diawali dari pengenalan alat dan bahan dilanjutkan dengan pembuatan sukade buah kunru. Setelah kegiatan selesai dilakukan pendampingan termasuk evaluasi kegiatan. Hasil dari kegiatan ini berdasarkan hasil uji hipotesis komparatif antara minat berwirausaha sebelum dan sesudah kegiatan dengan Paired Samples Test didapatkan nilai sig. (2- tailed) adalah $0.008<0.05$ $(\alpha=5 \%)$. Hal tersebut menunjukan bahwa ada pengaruh kegiatan pemberdayaan dengan kegiatan wirausaha dalam meningkatkan minat wirausaha masyarakat tana toraja.
\end{abstract}

Kata Kunci: masyarakat; sukade buah kunru; kegiatan usaha; minat wirausaha.

\begin{abstract}
The purpose of this activity is to increase the interest in entrepreneurship in the Tana Toraja community through empowerment with entrepreneurial activities. Entrepreneurship is the process of identifying, developing and bringing a vision into life. That vision can be innovative ideas, opportunities, better ways of doing things. The end result of this process is the creation of new ventures that are formed under conditions of risk or uncertainty. The method used in this activity is training to make skills in making products from kunru fruit, namely sukade which begins with the introduction of tools and materials followed by making kunru fruit sukade. After the activity is complete, assistance is carried out including activity evaluation. The results of this activity are based on the results of the comparative hypothesis test between the interest in entrepreneurship before and after the activity with the Paired Samples Test, the sig value is obtained. (2-tailed) was $0.008<0.05(\alpha=5 \%)$. This shows that there is an influence of empowerment activities with entrepreneurial activities in increasing the entrepreneurial interest of the Tana Toraja community.
\end{abstract}

Keywords: society; kundur fruit sukade; business activities; entrepreneurial interest.

\section{PENDAHULUAN}

Permasalahan

pengangguran merupakan permasalahan yang sampai saat ini belum bisa untuk diatasi oleh pemerintah nasional pada umumnya dan pemerintah daerah pada khususnya. Berbagai cara untuk mengatasi permasalahan ini sudah ditempuh oleh pemerintah namun masalah ini belum juga mampu untuk diselesaikan. Pengangguran ini muncul karena adanya ketidaksesuaian antara permintaan tenaga kerja dan penawaran tenaga kerja. Masalah pengangguran ini sangat penting untuk diperhatikan karena pengangguran itu sangat berpotensi menimbulkan kerawanan berbagai kriminal dan gejolak sosial, politik dan kemiskinan.

Pada 2030-2040, Indonesia diprediksi akan mengalami bonus demografi, yaitu penduduk dengan usia produktif lebih banyak dibandingkan dengan penduduk non produktif. Di masa ini juga diprediksi penduduk usia produktif mencapai $64 \%$ dari total penduduk Indonesia yang diperkirakan mencapai 297 juta jiwa. Oleh sebab itu, banyaknya penduduk dengan usia produktif harus diikuti oleh peningkatan kualitas, baik dari sisi pendidikan, 
keterampilan, dan semakin ketatnya persaingan di pasar tenaga kerja.

Menurut (I. L. Belakang, 2017) pada Agustus 2019, tingkat pengangguran terbuka mencapai 7,05 juta orang atau 5,28 \% dari jumlah angkatan kerja. Center of Reform on Economics (CORE) Indonesia memperkirakan jumlah pengangguran terbuka pada kuartal kedua 2020 akan bertambah 4,25 juta orang. Angka tersebut merupakan proyeksi yang dibuat CORE berdasarkan skenario ringan dampak pandemi corona. Sementara pada skenario sedang akan terdapat tambahan 6,68 juta orang yang menganggur, sedangkan pada skenario berat sebanyak 9,35 juta orang.

Menurut data BPS tahun 2018 garis kemiskinan dan penduduk miskin di Kabupaten Tana Toraja dari tahun 2010 sebanyak 185.785 poverty line dengan jumlah penduduk miskin $14,62 \%$, tahun 2011 sebanyak 196.785 poverty line dengan jumlah penduduk miskin 13,22\%, tahun 2012 sebanyak 208.436 poverty line dengan jumlah penduduk miskin 12,72\%, tahun 2013 sebanyak 217.981 poverty line dengan jumlah penduduk miskin 13,81\%, tahun 2014 sebanyak 226.762 poverty line dengan jumlah penduduk 12,77\%, tahun 2015 garis kemiskinan 238.838 dengan jumlah penduduk miskin 12,46\% sedangkan tahun 2016 garis kemiskinan sebanyak 251.452 dengan persentase $12,36 \%$ dan tahun 2017 garis kemiskinan sebanyak 261.573 dengan persentase 12,62\% (L. Belakang, 2019).

Untuk mengatasi dampak
pengangguran dari pandemi ini khusunya untuk masyarakat desa Lili'kira kecamatan Nanggal Tana Toraja kami berinisiatif untuk melakukan pemberdayaan yaitu kegiatan wirausaha kepada masyarakat disana, sehingga nantinya masyarakat akan jadi lebih produktif dan bisa membuka peluang bisnis baru yang mampu mendatangkan keuntungan.

Kewirausahaan (entrepreneurship) muncul apabila seseorang individu berani mengembangkan usaha-usaha dan ide-ide barunya. Proses kewirausahaan meliputi semua fungsi, aktivitas, dan tindakan yang berhubungan dengan perolehan peluang dan penciptaan organisasi usaha (Suryana, 2001) dan tujuan kewirausahaan ternyata cukup penting dalam kehidupan bermasyarakat. Hal ini dikarenakan, kewirausahaan mampu membantu perekonomian warga sekitar menjadi lebih baik dengan terciptanya lapangan pekerjaan baru.

Tak hanya bermanfaat untuk masyarakat, dengan semakin banyaknya wirausahawan yang ada pada suatu negara, alhasil juga bisa meningkatkan ekonomi dan meningkatkan kualitas dari negara itu sendiri, kewirausahaan sendiri merupakan proses mengidentifikasi, mengembangkan, dan membawa visi ke dalam kehidupan. Visi tersebut bisa berupa ide dan gagasan, peluang, atau cara untuk lebih baik dalam menjalankan sesuatu hingga menghasilkan output berupa usaha baru.

Besarnya nilai sejarah dan perhatian dunia terhadap Tana Toraja juga menjadi salah satu kepedulian Pemerintah Indonesia dalam menjaga dan melestarikan heritage ini, maka dimasukkanlah Kawasan Tana Toraja dan sekitarnya ke dalam Kawasan Strategis Pariwisata Nasional Mandat PP No. 50/2011 Tentang RIPPARNA (Sedarmayanti, 2014:21). Oleh karena itu, penataan ruang diprioritaskan karena mempunyai pengaruh sangat penting secara nasional terhadap budaya, lingkungan, dan termasuk wilayah yang ditetapkan sebagai warisan dunia. Tana Toraja memegang peranan yang penting dalam perkembangan pariwisata di Indonesia khususnya di kawasan timur.

Sebagai daerah tujuan utama bagi wisatawan, tentu Tana Toraja tidak terlepas dari dampak pengembangan pariwisata dari segala aspek kehidupan termasuk kebudayaan. Fungsionalisme-Struktural salah satu paham atau perspektif di dalam sosiologi yang memandang masyarakat sebagai satu sistem yang terdiri dari bagian-bagian yang saling berhubungan satu sama lain dan bagian yang satu tak dapat berfungsi tanpa ada hubungan dengan bagian yang lain. Elemen-elemen itu antara lain adalah ekonomi, politik, hukum, agama, pendidikan, keluarga, kebudayaan, adat-istiadat, dan lain-lain (Ridwan et al., 2016). $\mathrm{Hal}$ ini relevan dengan pengelolaan wisata Toraja Utara sebagai sebuah sistem yang melibatkan banyak komponen wisata.

Dengan meningkatnya pengembangan pariwista di Tana Toraja ini akan lebih mudah kepada masyarakat disana untuk mengembangkan minat dan jiwa wirausahanya karena jika tempat wisata di suatu daerah bagus maka dipastikan tempat tersebut akan dikunjungi oleh banyak orang dan disinilah peluang masyarakat lokal disana dimana mereka bisa menjual dan memperkenalkan produk sukade buah kunru ini ke orang-orang yang dating berkunjung, bahkan selain masyarakat Indonesia, Toraja juga dikunjungi oleh wisatawan dari mancanegara.

Diharapkan nantinya kegiatan usaha ini akan meningkatkan minat berwirausaha masyarakat tana toraja melalui pemberdayaan serta kegiatan wirausaha terus berlanjut guna membuka peluang bisnis dan kerja di Tana Toraja bukan saja pada saat masa pandemi tapi masa-masa yang akan datang guna 
membantu perekonomian masyarakat.

\section{METODE}

Metode yang digunakan dalam kegiatan pengabdian masyarakat ini adalah kegiatan pelatihan yang melibatkan masyarakat di Desa Lili'kira kecamatan Nangalla Tana Toraja sejumlah 10 orang melalui beberapa tahapan sebagai berikut: Tahapan pertama, Kegiatan memperkenalkan alat dan bahan yang digunakan kepada masyarakat secara langsung. Tahapan kedua, Mengolah buah kunru menjadi sukade atau manisan kering serta mempraktikkan metode pemasarannya ke masyarakat secara langsung. Tahapan ketiga, mengevaluasi minat masyarakat terhadap pemasaran sukade atau manisan kering.

\section{HASIL DAN PEMBAHASAN}

Kegiatan pengabdian masyarakat ini dengan melakukan pemberdayaan dengan pelatihan membuat produk sukade buah untuk meningkatkan minat berwirausaha masyarakat Tana Toraja. Dengan hasil angket seperti pada Tabel 1.

Tabel 1. Data Hasil Minat Berwirausaha

\begin{tabular}{ccc}
\hline Angket & \multicolumn{2}{c}{ Minat Berwirausaha } \\
\cline { 2 - 3 } No & Sebelum & Setelah \\
\hline 1. & 120 & 125 \\
2. & 100 & 130 \\
3. & 50 & 100 \\
4. & 80 & 110 \\
5. & 110 & 115 \\
6. & 115 & 120 \\
7. & 125 & 120 \\
8. & 75 & 95 \\
9. & 60 & 90 \\
10. & 85 & 100 \\
Rata-rata & 92 & 110.5 \\
\hline
\end{tabular}

\section{Pembahasan}

Dalam kegiatan pemberdayaan ini dilakukan dengan tiga tahapan yaitu (1) pengenalan alat dan bahan pembuatan produk; (2) Pemaparan pembuatan sukade buah kunru; (3) mempraktikkan proses pemasaran secara langsung.

\section{Pemberian Materi tentang Manfaat buah kunru}

Kunru (Benincasa hispida) merupakan komoditas pertanian yang tumbuh baik pada iklim tropis. Oleh sebab itu, buah kunru dapat tumbuh subur di Indonesia. Buah kunru (Benincasa hispida) menyerupai melon berdaging buah tebal yang berwarna putih dan berair. Buah kunru mengandung air, protein, lemak nabati, karbohidrat, serat, mineral dan vitamin (Grubben \& Denton, 2004). Kunru memiliki nama berbeda di setiap daerahnya, di Sumatera Barat disebut kundua batang, blonceng di Jawa Tengah, kondur di Maluku dan gundur di Kalimantan.

Buah kunru biasanya dikonsumsi dalam bentuk jus atau sari buah kunru. Buah kunru juga diolah sebagai sayuran bergizi karena memberikan sumber gizi yang baik untuk tubuh seperti, gula alami, asam amino, asam organik, unsur mineral dan vitamin. Berbagai penelitian membuktikan bahwa buah kunru memiliki khasiat obat seperti anti-diare, anti-obesitas, anti-tukak lambung, antidepresan, pengobatan diabetes mellitus, dan antioksidan yang berasal dari buah kunru.

Pada tahapan pertama ini kami memperlihatkan tampilan buah kunru kepada masyarakat (Gambar 1), hal ini dilakukan agar mereka dapat mengetahui bentuk buah ini karena kebanyakan dari mereka tidak tahu bagaimna bentuk buah ini.

Pentingnya penanaman jiwa usaha adalah untuk melatih kemandirian masyarakat. Wirausaha bisa dilakukan siapa saja, selain itu berrwirausaha juga mampu melatih kreatifitas seseorang agar terus berinovatif. Berwirausaha itu tidak mudah tapi tidak ada salahnya mencoba dan mengambil risiko yang ada.

(Prevention et al., 2007) mengatakan bahwa "Entrepreneur is one who shifts economic resources out of an area of lower and into an area of higher productivity and greater yield' yaitu bahwa pengusaha adalah salah satu yang bergeser sumber daya ekonomi dari daerah yang lebih rendah dan menjadi wilayah produktivitas yang lebih tinggi dan hasil yang lebih besar.

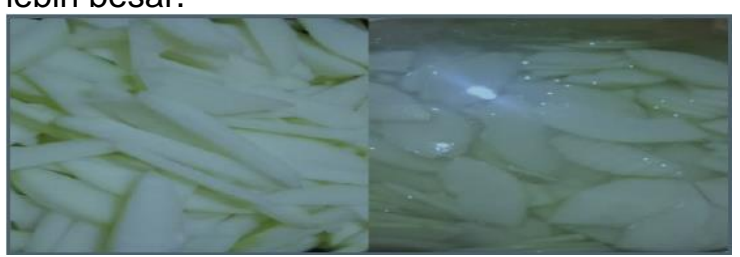

Gambar 1. Tampilan buah kunru

\section{Proses Pembuatan Sukade Kunru}

Sebelum proses pembuatan sukade kunru, kelompok kami mencoba menjelaskan materi kepada para masyarakat tentang langkah-langkah yang digunakan dalam pembuatan sukade buah kunru serta hal-hal yang harus diperhatikan dalam pembuatannya.

Proses pembuatan sukade buah kunru pada masyarkat pertama yang dilakukan adalah mempersiapkan wadah sebagai tempat untuk menampung buah kunru serta gula yang sudah disiapkan sebelumnya, kemudian kunru yang sudah diiris dibersihkan lalu ditiriskan sampai airnya kering. Pada proses selanjutnya adalah dilakukan pencampuran dengan 
memasak gula dan air secara bersama-sama. Berikut adalah gambar kegiatan persiapan alat dan bahan (Gambar 2 dan Gambar 3).

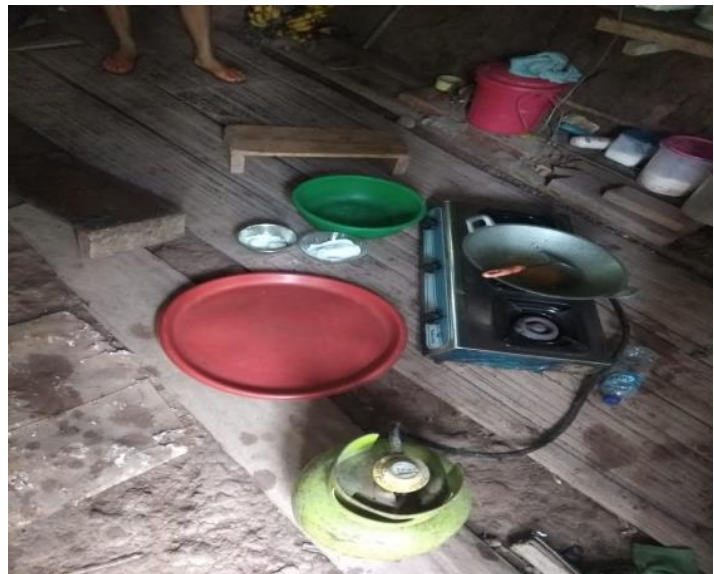

Gambar 2. Proses persiapan alat dan bahan

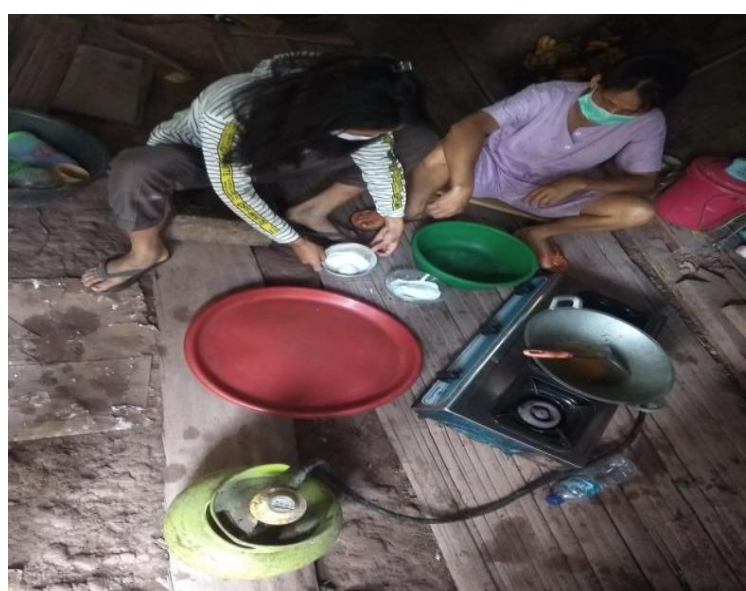

Gambar 3. Proses pengadukan bahan-bahan

Setelah pengadukan selesai dilakukan untuk maka sukade buah kunru telah selesai, proses pemasakannya dilakukan kurang lebih sekitar 20-30 menit dan jika air gula sudah mengering dan mengkristal itu artinya sukade buah kunru telah siap untuk dikonsumsi (Gambar 3).

Setelah pembungkusan, dilakukan proses pemasaran kepada konsumen secara langsung. Untuk pemasaran untuk sementara akan dilakukan secara langsung yaitu menitipkan ke kios-kios atau warung-warung dan untuk pemasaran online masih belum dilakukan (Gambar 4).

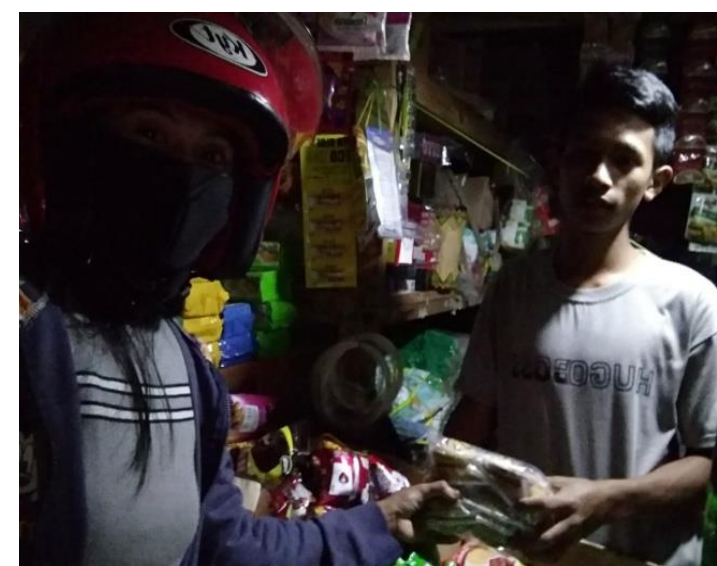

Gambar 4. Penitipan produk kewarung-warung

\section{Kegiatan Evaluasi}

Kegiatan evaluasi dalam kegiatan ini adalah dengan menelaah terhadap apa saja yang sudah dilakukan dari awal sampai selesai mulai dari pengenalan alat dan bahan dengan ceramah sampai kepada pembuatan sukade buah kunru apakah sesuai dengan tahapannya ataukah masih ada kekurangan dan juga kegiatan pendampingan yaitu dengan memberi kesempatan para masyarakat untuk mencoba melakukan pembuatan sukade buah kunru dengan pengawasan kelompok kami.

\section{Peningkatan Minat Berwirausaha sebelum dan sesudah penerapan kegiatan wirausaha Wirausaha adalah proses} mengidentifikasi, mengembangkan, dan membawa visi ke dalam kehidupan. Visi tersebut bisa berupa ide inovatif, peluang, cara yang lebih baik dalam menjalankan sesuatu. Hasil akhir dari proses tersebut adalah penciptaan usaha baru yang dibentuk pada kondisi risiko atau ketidakpastian.

Demikian pula kegiatan wirausaha mampu memberikan hasil positif terhadap peningkatan minat berwirausaha masyarakat. Dari penelitian ini pada Tabel 1 didapatkan bahwa nilai rata-rata minat berwirausaha terjadi kenaikan dari 95 menjadi 110.5 sebelum dan sesudah penerapan kegiatan wirausaha ini.

Berdasarkan hasil uji hipotesis komparatif dengan Paired Samples Test di dapatkan nilai sig. (2- tailed) adalah $0.008<$ $0.05(\alpha=5 \%)$. Sehingga dapat disimpulkan bahwa terdapat perbedaan minat berwirausaha sebelum dan sesudah melakukan kegiatan wirausaha.

Menurut (Wirausahawan, n.d.) mengemukakan bahwa minat merupakan kecenderungan jiwa seseorang terhadap suatu objek, dan biasanya kecenderungan jiwa tersebut disertai dengan perasaan senang karena merasa memiliki kepentingan terhadap sesuatu itu yang diminatinya tersebut dan menurut (Hudaya et al., 2020), minat adalah 
rasa lebih suka dan rasa keter-tarikan pada suatu hal atau aktivitas, tanpa ada yang menyuruh.

Peningkatan minat sebelum dan sesudah pelatihan mengalami peningkatan karena masyarkat sebelum kegiatan dilaksanakan belum mengetahui pelatihan apa yang diberikan, namun setelah kegiatan dilaksanakan masyarakat mengetahuinya dengan baik, karena minat itu akan muncul ketika seseorang telah mengalami kesuksesan atau keberhasilan dalam mengerjakan sesuatu sedangkan menurut (Hudaya et al., 2020), minat diartikan sebagai kecenderungan subyek yang menetap, untuk tertarik pada bidang studi atau pokok bahasan tertentu dan merasa senang mempelajari materi tersebut.

\section{SIMPULAN}

Kegiatan pemberdayaan masyarakat Tana Toraja dengan kegiatan wirausaha dapat meningkatkan minat wirausaha masyarakat yaitu dengan melaksanakan kegiatan berupa pelatihan membuat sukade buah kunru dan diperlukan kegiatan lanjutan berupa program untuk analisis usaha sukade buah kunru.

\section{DAFTAR RUJUKAN}

Belakang, I. L. (2017). I. pendahuluan. 20082010.

Belakang, L. (2019). BAB I. 13, 1-5.

Hudaya, A., Aqil, D. I., \& Masri, Z. A. H. (2020). Pemberdayaan remaja pesantren melalui biopreneurship pembuatan nugget tempe guna menumbuhkan minat berwirausaha Empowerment of pesantren adolescents through biopreneurship making nugget tempeto use an interest in enterprises. $7(1), 36-44$.

Prevention, U., Taruna, K., \& Taruna, E. (2007). Efektivitas program penanggulangan pengangguran karang taruna "eka taruna bhakti" desa sumerta kelod kecamatan denpasar timur kota denpasar. 2.

Ridwan, M., Fatchan, A., \& Astina, I. K. (2016). Potensi Objek Wisata Toraja Utara Berbasis Kearifan Lokal Sebagai Sumber Materi Geografi Pariwisata. Jurnal Pendidikan - Teori, Penelitian, Dan Pengembangan, 1(1), 1-10. https://doi.org/10.17977/jp.v1i1.6601

Setiawan, S. A. (2018). Mengoptimalkan Bonus Demografi untuk Mengurangi Tingkat Kemiskinan di Indonesia. Jurnal Analis Kebijakan, 2(2), 11-23.

Wirausahawan, P. (n.d.). Sikap dan Perilku Wirausahawan. 6551-6586. 